\title{
FAKTOR-FAKTOR YANG BERHUBUNGAN DENGAN KEJADIAN PREEKLAMPSIA DI INDONESIA
}

\author{
Anita Setyawati ${ }^{1}$, Restuning Widiasih ${ }^{1}$, Ermiati $^{1}$ \\ ${ }^{1}$ Fakultas Keperawatan, Universitas Padjadjaran \\ anitasetyawati03@gmail.com/anita.setyawati@unpad.ac.id
}

\begin{abstract}
Abstrak
Preeklampsia adalah kelainan multisistemik spesifik pada kehamilan yang ditandai oleh timbulnya hipertensi dan proteinuria setelah umur kehamilan 20 minggu. Kondisi yang terjadi pada kasus preeklampsia perlu ditangani dengan tepat karena preeklampsia dapat menimbulkan komplikasi yang serius pada ibu dan janin. Sementara itu, hingga saat ini penyebab preeklampsia belum diketahui secara pasti. Namun demikian, beberapa penelitian telah mengidentifikasi faktor-faktor yang berhubungan dengan kejadian preeklampsia. Sehingga, studi literatur ini dilakukan untuk mengidentifikasi faktorfaktor yang berhubungan dengan preeklampsia berdasarkan hasil penelitian yang telah dilakukan di Indonesia. Studi literatur ini dilakukan dengan cara melakukan pencarian artikel pada google cendekia, pengkategorian artikel sesuai kriteria inklusi, dan analisis artikel. Kata kunci yang digunakan dalam pencarian artikel adalah : faktor-faktor dan preeklampsia. Pada pengaturan lanjutan ditentukan artikel yang dicari adalah artikel pada tahun 2008-2018. Dalam pencarian tersebut didapatkan 887 artikel. Kriteria inklusi yang digunakan dalam pencarian artikel adalah : (1) artikel berisi tentang kejadian preeklampsia di Indonesia, (2) kata kunci yang digunakan dalam pencarian ada dalam judul artikel, dan (3) rancangan penelitian dalam artikel menggunakan case control design. Berdasarkan kriteria inklusi tersebut, maka didapatkan 10 artikel yang dapat dianalisis untuk studi literatur ini. Berdasarkan analisis yang telah dilakukan, telah teridentifikasi bahwa faktor-faktor resiko yang berhubungan dengan kejadian preeklampsia adalah karakteristik ibu, riwayat kehamilan, berat badan, riwayat penyakit kronis, pengetahuan, dan riwayat kontrasepsi. Faktor-faktor resiko yang telah teridentifikasi ini diharapakan dapat digunakan sebagai dasar untuk menganalisis program pencegahan preeklampsia dan menentukan penatalaksanaan yang lebih tepat pada ibu hamil dengan preeklampsi di Indonesia.
\end{abstract}

Kata kunci: faktor, preeklampsia

Abstract
Literature Study: Related Factors With Preeclampsia Events In Indonesia. Preeclampsia is a specific multisystemic disorder in pregnancy characterized by the onset of hypertension and proteinuria after 20 weeks' gestation. Conditions that occur in cases of preeclampsia need to be handled appropriately because preeclampsia can cause serious complications in the mother and fetus. Meanwhile, until now the cause of preeclampsia is not known for certain. Nevertheless, several studies have identified factors associated with the incidence of preeclampsia. Thus, this literature study was conducted to identify factors related to preeclampsia based on the results of studies that have been conducted in Indonesia. This literature study is done by doing an article search on google scholar, categorizing articles according to inclusion criteria, and article analysis. The keywords used in article search are: factors and preeclampsia. In the advanced settings specified article sought is an article in 2008-2018. In this search 887 articles were obtained. The inclusion criteria used in article search are: (1) articles containing the incidence of preeclampsia in Indonesia, (2) the keywords used in the search are in the title of the article, and (3) the research design in the article using case control design. Based on the inclusion criteria, 10 articles can be analyzed for this literature study. Based on the analysis that has been done, has been identified that risk factors associated with the incidence of preeclampsia are mother characteristics, pregnancy history, body weight, history of chronic diseases, knowledge, and history of contraception. These identified risk factors are expected to be used as a basis for analyzing prevention programs of preeclampsia and establishing more appropriate management in pregnant women with preeclampsia in Indonesia.

Keywords: factor, preeclampsia 


\section{Pendahuluan}

Dalam kerangka Sustainable

Development Goals (SDGs), menurunkan Angka Kematian Ibu (AKI) masih menjadi salah satu target utama bidang kesehatan(World Health Organization, 2016). WHOmencanangkan bahwa AKIdiharapkan menurun hingga 70 per 100.000 kelahiran hidup pada tahun 2030 (World Health Organization, 2016). Sementara berdasarkan Survei Demografi Kependudukan Indonesia (SDKI) tahun 2015, AKI di Indonesia adalah 305 per 100.000 kelahiran hidup(Dinas Kesehatan Provinsi Jawa Barat, 2015).

AKI adalah jumlah kematian ibu selama masa kehamilan, persalinan, dan nifas yang disebabkan oleh kehamilan, persalinan, dan nifas serta pengelolaannya tetapi bukan karena sebab - sebab lain seperti kecelakaan, terjatuh, dan lain - lain di setiap $100.000 \quad$ kelahiran hidup(KementerianKesehatanRepublikInd onesia, 2011). Seiring dengan pernyataan di atas, Badan Penelitian dan Pengembangan Kesehatan Kementerian Kesehatan mengungkapkan bahwa penyebab tertinggi AKI di Indonesia adalah $32,4 \%$ hipertensi dan/atau preeklampsia serta $20,3 \%$ perdarahan post partum.

Preeklampsia adalah kelainan multisistemik spesifik pada kehamilan yang ditandai oleh timbulnya hipertensi dan proteinuria setelah umur kehamilan 20 minggu (Rahmadhayanti, Hayati, \& Saleh, 2014). Kondisi yang terjadi pada kasus preeklampsia perlu ditangani dengan tepat karena preeklampsia dapat menimbulkan komplikasi yang serius pada ibu dan janin. Komplikasi yang dapat terjadi pada ibu dan janin meliputi komplikasi maternal dan komplikasi fetal yang dapat mengancam nyawa(Heazell, 2010).

Sementara itu, hingga saat ini penyebab preeklampsia belum diketahui secara pasti(Velde, Scholefield, \& Plante, 2013). Namun demikian, resiko preeklampsia diketahui dapat meningkat pada ibu hamil dengan primigravida; grandmultigravida; kehamilan yang langsung terjadi setelah perkawinan; ibu hamil dengan usia kurang dari 20 tahun atau lebih dari 35 tahun; janin besar; kehamilan lebih dari satu (kembar); morbid obesitas; riwayat preeklampsia pada kehamilan sebelumnya; riwayat keluarga dengan preeklampsia; ibu hamil dengan gangguan fungsi organ (diabetes mellitus, penyakit ginjal, migrain, dan hipertensi); serta ibu hamil dengan hydrops foetalis, mola hidatidosa, anti fosfolipid antibodies, dan infeksi saluran kemih (Bobak, Lowdermilk, \& Jensen, 2004; Cunningham et al., 2012).

Akan tetapi, faktor resiko preeklampsia di atas merupakan faktor resiko yang didapatkan dari hasil-hasil penelitian di Luar Indonesia. Padahal di Indonesia juga terdapat hasil-hasil penelitian yang meneliti faktor-faktor yang berhubungan dengan kejadian preeklampsia. Hasil-hasil penelitian yang mengidentifikasi adanya faktor resiko preeklampsia di Indonesia tentu dapat digunakan sebagai dasar untuk menganalisis program pencegahan preeklampsia dan menentukan penatalaksanaan yang lebih tepat pada ibu hamil dengan preeklampsia. Oleh karena itu, studi literatur ini dilakukan untuk mengidentifikasi faktor-faktor yang berhubungan dengan kejadian preeklampsia di Indonesia.

\section{Metode}

Studi literatur ini dilakukan dengan cara melakukan pencarian artikel pada google cendekia, pengkategorian artikel sesuai kriteria inklusi, dan analisis artikel. Kata kunci yang digunakan dalam pencarian artikel adalah : faktor-faktor dan preeklampsia. Pada pengaturan lanjutan ditentukan artikel yang dicari adalah artikel pada tahun 2008-2018. Dalam pencarian tersebut didapatkan 887 artikel. Kriteria inklusi yang digunakan dalam pencarian artikel adalah : (1) artikel berisi tentang kejadian preeklampsia di Indonesia, (2) kata kunci yang digunakan 
dalam pencarian ada dalam judul artikel, dan (3) rancangan penelitian dalam artikel menggunakan case control design. Berdasarkan kriteria inklusi tersebut, maka didapatkan sepuluh artikel yang dapat dianalisis untuk studi literatur ini.

\section{Hasil}

Berdasarkan sepuluh artikel yang dianalisis, didapatkan enam kategori faktor resiko yang berhubungan dengan kejadian preeklampsia di Indonesia, antara lain : karakteristik ibu hamil, riwayat kehamilan, peningkatan berat badan atau obesitas, riwayat penyakit kronis, pengetahuan tentang kehamilan dan masalah kehamilan, serta riwayat kontrasepsi hormonal. Hasil studi literatur ini ditampilkan pada tabel 1.
Kategori faktor resiko karakteristik ibu hamilterdiri dari usia, tingkat pendidikan terakhir, dan pekerjaan.

Tabel 1 menunjukkan bahwa sembilan dari sepuluh artikel menunjukkan bahwa terdapat hubungan yang signifikan antara usia dengan kejadian preeklampsia $(\mathrm{p}<0,05)$ (Agustin \& Indriani, 2013; Aidah, Suesti, \& Sulistyaningsinh, 2013; Andriyani, 2012; Astuti, 2016; Nurhasanah \& Indriani, 2017; Saraswati \& Mardiana, 2016; Situmorang, Damantalm, Januarista, \& Sukri, 2016; Umar \& Wardani, 2017; Yani \& Suyani, 2017). Penelitianpenelitian tersebut mengelompokkan usia berdasarkan kelompok usia beresiko $(<20$ tahun dan $>35$ tahun) dan kelompok usia tidak beresiko (20-35 tahun).

Tabel 1.

Kategori Faktor-Faktor yang Berhubungan dengan Kejadian Preeklampsia

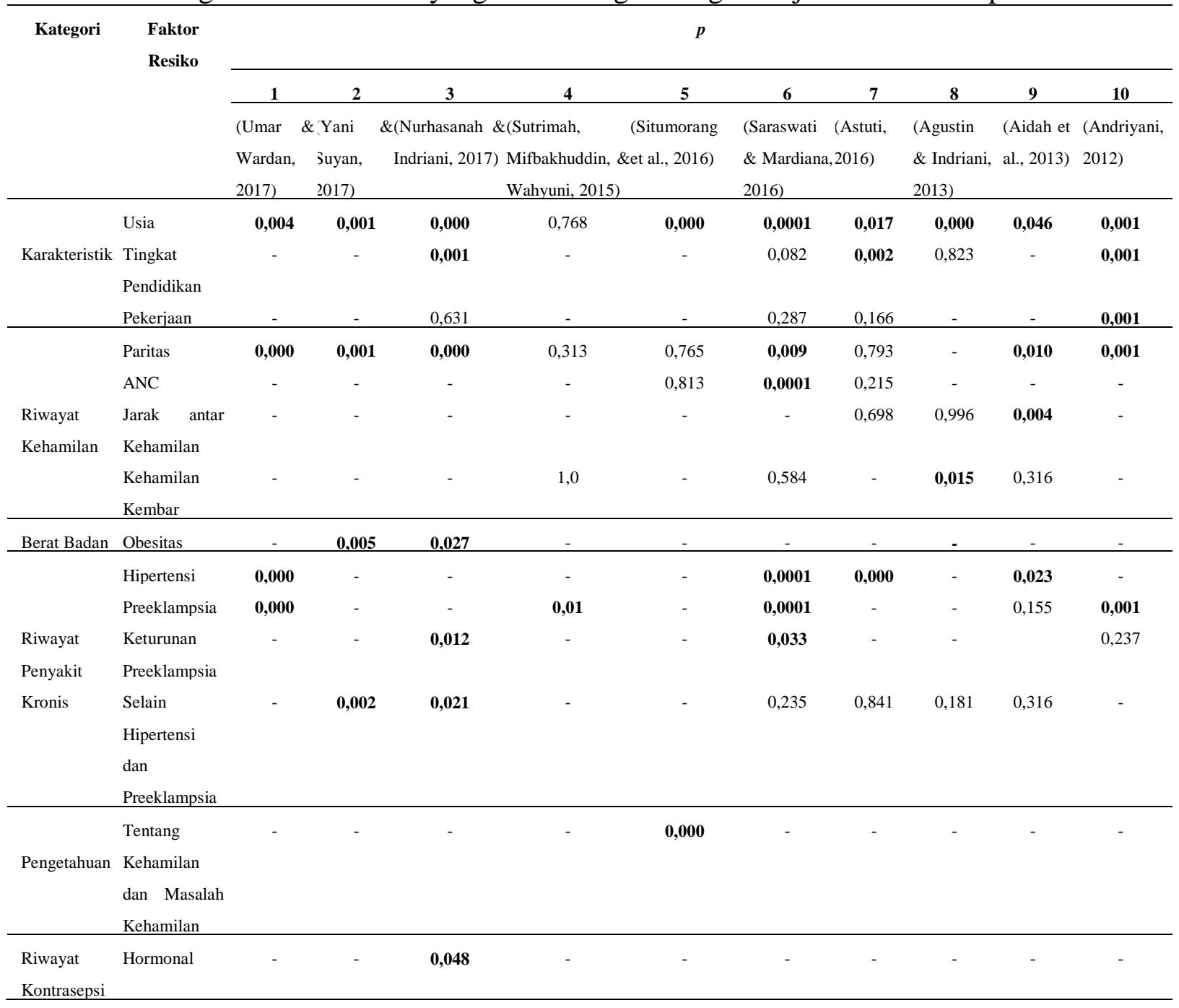




\section{Pembahasan}

Satu dari sembilan hasil penelitian tersebut menunjukkan bahwa ibu yang berusia $<20$ atau $>35$ tahun memiliki kemungkinan 3-4 kali lebih besar untuk mengalami preeklampsia dibandingkan dengan ibu yang berusia 20-35 tahun(Agustin \& Indriani, 2013). Hal ini dikarenakan oleh usia dapat mempengaruhi peningkatan dan penurunan fungsi tubuh manusia serta status kesehatan manusia yang dalam hal ini adalah ibu hamil(Situmorang et al., 2016).Pada usia $<20$ tahun diketahui bahwa organ reproduksi perempuan belum siap dan atau matang secara sempurna, sementara pada usia > 35 tahun atau semakin bertambahnya usia ibu hamil, dapat terjadi proses degeneratif yang menyebabkan terjadinya pengerasan dinding pembuluh darah yang selanjutnya menyebabkan terjadinya penyempitan pembuluh darah(Lowdermilk, Perry, \& Cashion, 2010). Sehingga aliran darah memerlukan tekanan darah yang lebih besar agar dapat melalui pembuluh darah. Hal ini ditunjukkan dengan adanya peningkatan tekanan darah sebagai salah satu tanda dari preeklampsia.

Tabel 1 juga menunjukkan bahwa lima dari sepuluh artikel meneliti tentang tingkat pendidikan terakhir sebagai faktor resiko terjadinya preeklampsia. Tiga dari lima artikel tersebut menunjukkan adanya hubungan yang signfikan antara usia dengan kejadian preeklampsia $(\mathrm{p}<0,05)$ (Andriyani, 2012; Astuti, 2016; Nurhasanah \& Indriani, 2017). Ketiga penelitian tersebut mengelompokkan tingkat pendidikan terakhir berdasarkan kelompok tingkat pendidikan rendah (SD dan SMP) dan kelompok tingkat pendidikan tinggi (SMA dan perguruan tinggi).Satu dari lima hasil penelitian tersebut menunjukkan bahwa ibu hamil dengan tingkat pendidikan terakhir SMP dan kebawahnya dapat mempengaruhi 2-3 kali lebih besar untuk terjadinya preeklampsia. Hal ini dapat disebabkan oleh semakin banyak pendidikan yang didapat, maka seseorang akan lebih terbiasa menerima dan memahami informasi yang diberikan. Sehingga ibu hamil dengan tingkat pendidikan lebih tinggi akan lebih mudah memahami informasi kesehatan tentang kehamilan dan berpikir lebih rasional dalam menghadapi masalah pada kehamilan yang salah satunya mengarah pada kejadian preeklampsia.

Selanjutnya tabel 1 menunjukkan bahwa empat dari sepuluh artikel meneliti tentang status pekerjaan sebagai faktor resiko terjadinya preeklampsia. Satu dari empat artikel tersebut menunjukkan bahwa terdapat hubungan yang signifikan antara status pekerjaan dengan kejadian preeklampsia ( $\mathrm{p}=0,001)$ (Andriyani, 2012). Hasil penelitiannya mendapatkan bahwa ibu yang bekerja mempunyai kemungkinan 4 kali lebih besar untuk mengalami preeklampsia dibandingkan dengan ibu yang tidak bekerja. Hal ini sejalan dengan teori Klonof bahwa perempuan yang bekerja di luar rumah memiliki resiko lebih tinggi untuk mengalami preeklampsia jika dibandingkan dengan ibu rumah tangga. Pekerjaan dikaitkan dengan adanya aktifitas fisik dan stres (Agustin, 2016). Sementara itu, adanya stres pada tubuh seseorang dapat merangsang pelepasan endotel pada pembuluh darah yang dapat menyebabkan vasokonstriksi pembuluh darah dan mengakibatkan peningkatan tekanan darah yang mengarah pada preeklampsia (Agustin \& Indriani, 2013). Selain itu, pengaruh stres akan merangsang kelenjar anak ginjal atau adrenal untuk mengeluarkan hormon adrenalin. Hormon adrenalin akan bekerja dan memacu denyut jantung lebih cepat yang berdampak pada peningkatan tekanan darah (Nurhasanah \& Indriani, 2017).

Sementara kategori faktor resiko riwayat kehamilan terdiri dari faktor resiko paritas, antenatal care (ANC), jarak antar kehamilan, dan kehamilan kembar.

Tabel 1 menunjukkan bahwa sembilan dari sepuluh artikel meneliti tentang status paritas sebagai faktor resiko 
kejadian preeklampsia. Enam dari sembilan artikel tersebut menunjukkan adanya hubungan yang signifikan antara status paritas dengan kejadian preeklampsia $(\mathrm{p}<0,05)$ (Aidah et al., 2013; Andriyani, 2012; Nurhasanah \& Indriani, 2017; Saraswati \& Mardiana, 2016; Umar \& Wardani, 2017; Yani \& Suyani, 2017). Hasil penelitian Aidah et al. (2013) membuktikan bahwa ibu hamil primipara memiliki kemungkinan 4-5 kali lebih besar untuk mengalami preeklampsia dibandingkan dengan ibu hamil multipara bahkan grande multipara. Hal ini dapat terjadi karena pada kehamilan pertama cenderung terjadi kegagalan pembetukan blocking antibodies terhadap antigen plasenta sehingga timbul respon imun yang tidak menguntungkan yang mengarah pada preeklampsia.

Pada tabel 1 juga ditunjukkan bahwa terdapat tiga dari sepuluh artikel yang meneliti tentang riwayat ANC sebagai faktor resiko terjadinya preeklampsia. Satu dari tiga artikel tersebut menunjukkan bahwa terdapat hubungan yang signifikan antara riwayat mengikuti ANC dengan kejadian preeklampsia $(\mathrm{p}=0,0001)$ (Saraswati \& Mardiana, 2016). Hasil penelitiannya mendapatkan bahwa ibu hamil yang tidak mengikuti ANC memiliki kemungkinan 17 kali lebih besar untuk mengalami preeklampsia dibandingkan dengan ibu hamil yang mengikuti ANC. Hal ini berkaitan dengan pernyataan Kementerian Keseharan Republik Indonesia bahwa melalui ANC ibu hamil bisa mendapatkan informasi kesehatan tentang tumbuh kembang kehamilannya serta dapat mengenali secara dini adanya penyulit dalam kehamilannya, sehingga dapat terhindar dari preeklampsia.

Tabel 1 juga menunjukkan bahwa terdapat tiga dari sepuluh artikel yang meneliti tentang jarak antar kehamilan sebagai faktor resiko terjadinya preeklampsia. Satu dari tiga artikel tersebut menunjukkan bahwa terdapat hubungan yang signifikan antara riwayat lama jarak antar kehamilan dengan kejadian preeklampsia $(\mathrm{p}=0,004)$ (Aidah et al., 2013). Hasil penelitiannya membuktikan bahwa ibu hamil dengan jarak antar kehamilan $<2$ atau $>5$ tahun memiliki kemungkinan 2-3 kali lebih besar untuk mengalami preeklampsia jika dibandingkan dengan ibu hamil yang memiliki jarak antar kehamilan 2-5 tahun. Hal ini dapat dikarenakan sumber biologis tubuh ibu secara sistematis akan terpakai selama masa kehamilan, dan untuk kehamilan berikutnya membutuhan waktu 2-5 tahun agar kondisi tubuh ibu kembali seperti kondisi sebelum hamil. Apabila terjadi kehamilan berikutnya sebelum 2 tahun, maka kesehatan ibu dapat mengalami kemunduran secara progresif.

Selain itu tabel 1 juga menunjukkan bahwa terdapat empat dari sepuluh artikel yang meneliti tentang kehamilan kembar sebagai faktor resiko terjadinya preeklampsia. Satu dari empat artikel tersebut menunjukkan bahwa terdapat hubungan yang signifikan antara kehamilan kembar dengan kejadian preeklampsia $(\mathrm{p}=0,015) \quad$ (Agustin \& Indriani, 2013). Hasil penelitian tersebut sejalan dengan hasil penelitian Kristen et al. (2015) bahwa ibu hamil kembar memiliki kemungkinan 3 kali lebih besar untuk mengalami preeklampsia.

Sementara itu, berdasarkan kategori faktor resiko berat badan (obesitas), didapatkan dua dari sepuluh artikel yag meneliti tentang obesitas sebagai faktor resiko terjadinya preeklampsia. Kedua artikel tersebut menunjukkan bahwa terdapat hubungan yang signifikan antara obesitas dengan kejadian preeklampsia $(\mathrm{p}<0,05)$ (Nurhasanah \& Indriani, 2017; Yani \& Suyani, 2017). Hasil penelitian tersebut membuktikan bahwa ibu hamil dengan obesitas memiliki kemungkinan 23 kali lebih besar ntuk mengalami preeklampsia dibandingkan ibu hamil yang tidak obesitas. Obesitas disebabkan karena banyak faktor seperti faktor genetik, gangguan metabolik, dan konsumsi makanan yang berlebihan. Semakin gemuk seseorang maka jumlah darah yang ada 
pada tubuh juga akan semakin banyak sehigga akan semakin berat juga fungsi pompa jantungnya yang ditandai dengan peningkatan tekanan darah. Jika hal ini berlangsung terus menerus tanpa penanganan, maka hal ini dapat engarah pada terjadinya preeklampsia.

Berikutnya berdasarkan kategori faktor resiko riwayat penyakit kronis terdiri dari hipertensi, preeklampsia, keturunan preeklampsia, dan penyakit selain hipertensi.

Tabel 1 menunjukkan bahwa terdapat empat dari sepuluh artikel yang meneliti tentang riwayat hipertensi sebagai faktor resiko terjadinya preeklampsia. Keempat artikel tersebut menunjukkan bahwa terdapat hubungan yang signifikan antara riwayat hipertensi dengan kejadian preeklampsia ( $<<0,05)$ (Aidah et al., 2013; Astuti, 2016; Saraswati \& Mardiana, 2016; Umar \& Wardani, 2017). Hasil penelitian Umar dan Wardani (2017) serta Saraswati dan Mardiana (2016) membuktikan bahwa ibu hamil dengan riwayat hipertensi memiliki kemungkinan 6 kali lebih besar untuk mengalami preeklampsia dibandingkan dengan ibu hamil yang tidak memiliki riwayat hipertensi. Hal ini selaras dengan pernyataan(Cunningham et al., 2012)bahwa pada sebagian ibu hamil dengan riwayat hipertensi kronis, maka dapat tarjadi perburukan kondisi hipertensi pada kehamilan berikutnya. hipertensi yang diperberat oleh kehamilan dapat disertai dengan proteinuria atau edema patologis yang kemudian disebut dengan superimposed preeclampsia.

Tabel 1 juga menunjukkan bahwa terdapat lima dari sepuluh artikel yang meneliti tentang riwayat preeklampsia sebagai faktor resiko terjadinya preeklampsia. Empat dari lima artikel tersebut menunjukkan bahwa terdapat hubungan yang signifikan antara riwayat preeklampsia dengan kejadian preeklampsia $(\mathrm{p}<0,05)$ (Andriyani, 2012; Saraswati \& Mardiana, 2016; Sutrimah et al., 2015; Umar \& Wardani, 2017). Hasil penelitian Saraswati dan Mardiana (2016) membuktikan bahwa ibu hamil dengan riwayat preeklampsia pada kehamilan sebelumnya memiliki kemungkinan 20 kali lebih besar untuk mengalami preeklampsia.

Pada tabel 1 juga didapatkan bahwa terdapat tiga dari sepuluh artikel yang meneliti tentang riwayat keturunan preeklampsia sebagai faktor resiko terjadinya preeklampsia. Dua dari tiga artikel tersebut menunjukkan bahwa terdapat hubungan yang signifikan antara riwayat keturunan preeklampsia dengan kejadian preeklampsia $\quad(\mathrm{p}<0,05)$ (Nurhasanah \& Indriani, 2017; Saraswati \& Mardiana, 2016). Hasil penelitian Saraswati dan Mardiani (2016) membuktikan bahwa ibu hamil dengan riwayat keturunan preeklampsia pada ibu dan keluarganya memiliki kemungkinan 23 kali lebih besar mengalami preeklampsia dibandingkan dengan ibu hamil yang tidak mempunyai riwayat keturunan preeklampsia. Hasil penelitian ini membuktikan teori Norwitz (2008) yang menyatakan bahwa preeklampsia merupakan sindrom yang diturunkan. Sindrom ini lebih sering ditemukan pada anak perempuan dari ibu yang mempunyai riwayat preeklampsia atau mempunyai riwayat preeklampsia dalam keluarganya.

Selain itu tabel 1 menunjukkan bahwa terdapat enam dari sepuluh artikel yang meneliti tentang riwayat penyakit selain hipertensi dan preeklampsia sebagai faktor resiko terjadinya preeklampsia. Dua dari enam artikel tersebut menunjukkan bahwa terdapat hubungan yang signifikan antara riwayat penyakit selain hipertensi dan preeklampsia dengan kejadian preeklampsia $(\mathrm{p}<0,05) \quad$ (Nurhasanah \& Indriani, 2017; Yani \& Suyani, 2017). Hasil penelitian Nurhasanah (2017) membuktikan bahwa ibu hamil dengan riwayat menderita penyakit kronis memiliki kemungkinan 2 kali lebih besar untuk mengalami preeklampsia dibandingkan dengan ibu hamil yang tidak menderita riwayat penyakit kronis. Angka kejadian preeklampsia akan meningkat 
pada ibu hamil yang memiliki riwayat penyakit kronis sebelumnya karena pembuluh darah plasenta sudah mengalami gangguan sebelumnya.

Selanjutnya berdasarkan kategori
faktor resiko pengetahuan tentang
kehamilan dan masalah kehamilan,
terdapat satu dari sepuluh artikel yang meneliti tentang pengetahuan sebagai faktor resiko terjadinya preeklampsia. Artikel tersebut menunjukkan bahwa terdapat hubungan yang signifikan antara pengetahuan dengan kejadian preeklampsia $(\mathrm{p}=0,000)$ (Situmorang et al., 2016). Ibu hamil dalam penelitian tersebut mengatakan bahwa pengetahuan tentang kehamilan dan masalah kehamilan sangat penting, karena dengan memiliki pengetahuan tentang kehamilannya, maka mereka dapat mengetahui dan mengatasi tanda dan gejala dari masalah yang dialaminya. Selain itu, dengan pengetahuan yang baik, ibu hamil dapat terlindungi dari kecemasan dalam menghadapi masalah kehamilan sehingga tercapai derajat kesehatan yang baik bagi ibu hamil.

Sementara itu berdasarkan faktor resiko riwayat kontrasepsi hormonal, terdapat satu dari sepuluh artikel yang meneliti tentang riwayat kontrasepsi hormonal sebagai faktor resiko terjadinya preeklampsia. Artikel tersebut menunjukkan bahwa terdapat hubungan yang signifikan antara riwayat kontrasepsi hormonal dengan kejadian preeklampsia $(\mathrm{p}=0,048)$ (Nurhasanah \& Indriani, 2017). Hasil penelitian tersebut membuktikan bahwa ibu hamil dengan riwayat penggunaan kontrasepsi hormonal memiliki kemungkinan 1-2 kali lebuh besar untuk mengalami preeklampsia dibandingkan dengan ibu hamil yang tidak memiliki riwayat penggunaan kontrasepsi hormonal. Sebagian besar kontrasepsi hormonal mengandung hormon estrogen dan progesteron. Hormon dalam kontrasepsi ini telah diatur sedemikian rupa sehingga mendekati kadar hormon dalam tubuh akseptor. Namun jika digunakan dalam jangka waktu yang lama akan menimbulkan efek samping lain. Kedua hormon tersebut memiliki kemampuan untuk memperoleh retensi ion natrium dan sekresi air disertai kenaikan aktivitas renin plasma dan pembentukan angiotensin sehingga dapat memicu terjadinya peningkatan tekanan darah yang mengarah pada preeklampsia.

\section{Simpulan dan Saran}

Berdasarkan hasil dan pembahasan di atas, maka studi literatur ini menunjukkan bahwa faktor-faktor resiko yang berhubungan dengan kejadian preeklampsia adalah karakteristik ibu, riwayat kehamilan, berat badan, riwayat penyakit kronis, pengetahuan, dan riwayat kontrasepsi. Faktor-faktor resiko yang telah teridentifikasi ini diharapakan dapat digunakan sebagai dasar untuk menganalisis program pencegahan preeklampsia dan menentukan penatalaksanaan yang lebih tepat pada ibu hamil dengan preeklampsi di Indonesia.

\section{Daftar Pustaka}

Agustin, D. P., \& Indriani. (2013). FaktorFaktor yang Berhubungan dengan Kejadian Preeklampsia pada Ibu Hamil di RSUD Panembahan Senopati Bantul Yogyakarta Tahun 2012. STIKES 'Aisyiyah Yogyakarta. Retrieved from http://digilib.unisayogya.ac.id/1341/

Aidah, S., Suesti, \& Sulistyaningsinh. (2013). Faktor-Faktor Resiko yang Berhubungan dengan Kejadian Preeklampsia pada Ibu Bersalin di RS PKU Muhammadiyah Yogyakarta Tahun 2010-2012. STIKES 'Aisyiyah Yogyakarta. Retrieved from

http://digilib.unisayogya.ac.id/id/epri $\mathrm{nt} / 1423$

Andriyani, R. (2012). Faktor Risiko Kejadian Pre-Eklampsia di RSUD Arifin Achmad. Jurnal Kesehatan 
Komunitas, 2(1), 1-5. https://doi.org/https://doi.org/10.2531 1/jkk.Vol2.Iss 1.38

Astuti, S. P. (2016). Faktor-Faktor Yang Berhubungan Dengan Kejadian Preeklampsia Kehamilan di Wilayah Kerja Puskesmas Pamulang Kota Tangerang Selatan Tahun 20142015. Retrieved from http://repository.uinjkt.ac.id/dspace/h andle/123456789/29646

Bobak, I. M., Lowdermilk, D. L., \& Jensen, M. D. (2004). Maternity Nursing. San Francisco: Mosby-Year Book.

Cunningham, F. G., Gants, N. F., Leveno, K. J., Gilstrap, L. C., Hault, J. C., \& Wenstrom, K. D. (2012). Williams Obstetrics. New York: McGraw-Hill.

Dinas Kesehatan Provinsi Jawa Barat. (2015). Angka Kematian Ibu. Retrieved from www.diskes.jabarprov.go.id

KementerianKesehatanRepublikIndonesia. (2011). Jaminan Persalinan, Upaya Terobosan Kementerian Kesehatan dalam Percepatan Pencapaian Target MDGs. Retrieved from http://www.kesehatanibu.depkes.go.i d/archives/99

Lowdermilk, Perry, \& Cashion. (2010). Maternity Nursing. Mosby.

Nurhasanah, D. N., \& Indriani. (2017). Faktor-Faktor yang Berhubungan dengan Kejadian Preeklampsia pada Ibu Hamil di RSUD Panembahan Senopati Bantul Tahun 2016. Universitas 'Aisyiyah Yogyakarta. Retrieved from http://digilib.unisayogya.ac.id/3028/

Rahmadhayanti, E., Hayati, L., \& Saleh, M. I. (2014). Hubungan Polimorfisme Gen Reseptor
Angiotensin II Tipe 11166 A / C Dengan Kejadian Preeklampsia. Majalah Kedokteran Sriwijaya, 46(1), 52-58. Retrieved from http://ejournal.unsri.ac.id/index.php/ mks/article/view/2682

Saraswati, N., \& Mardiana. (2016). Faktor Risiko yang Berhubungan dengan Kejadian Preeklampsia pada Ibu Hamil (Studi Kasus di RSUD Kabupaten Brebes Tahun 2014). Unnes Journal of Public Health, 5(2), 90-99. https://doi.org/10.15294/ujph.v5i2.10 106

Situmorang, T. H., Damantalm, Y., Januarista, A., \& Sukri. (2016). Faktor - Faktor yang Berhubungan dengan Kejadian Preeklampsia pada Ibu Hamil di Poli KIA RSU Anutapura Palu. Jurnal Kesehatan Tadulako, 2(1), 34-44.

Sutrimah, Mifbakhuddin, \& Wahyuni, D. (2015). Faktor-Faktor yang Berhubungan dengan Kejadian Preeklampsia pada Ibu Hamil di RS Roemani Muhammadiyah Semarang. Jurnal Kebidanan Universitas Muhammadiyah Semarang, 4(1). https://doi.org/https://doi.org/10.2671 4/jk.4.1.2015.1-10

Umar, M. Y., \& Wardani, P. K. (2017). Faktor-Faktor yang Berhubungan dengan Kejadian Pre-Eklampsia pada Perempuan Bersalin. JUrnal Ilmu Kesehatan Aisyah, 2(1), 45-50. https://doi.org/http://dx.doi.org/10.30 604/jika.v2i1.31

Velde, M. Van de, Scholefield, H., \& Plante, L. A. (Eds.). (2013). Maternal Critical Care. Cambridge: Cambridge University Press.

World Health Organization. (2016). Sustainable Development Goals. Retrieved from www.who.int 
Yani, N. A., \& Suyani. (2017). FaktorFaktor yang Berhubungan dengan Kejadian Preeklampsia di RSU PKU Muhammadiyah Kota Yogyakarta Tahun 2015-2016. UNiversitas
'Aisyiyah Yogyakarta. Retrieved from

http://digilib.unisayogya.ac.id/id/epri $\mathrm{nt} / 3019$ 